\title{
Effect of integrating physics education technology simulations on students' conceptual understanding in physics: A review of literature
}

\author{
Herbert James Banda $\odot^{1, *}$ and Joseph Nzabahimana $\odot^{2}$ \\ ${ }^{1}$ African Centre of Excellence for Innovative Teaching and Learning Mathematics and Science (ACEITLMS), \\ University of Rwanda-College of Education (UR-CE), Rukara campus P.O Box 55, \\ Rwamagana, Kayonza, Rwanda \\ ${ }^{2}$ University of Rwanda-College of Education (UR-CE), Rukara campus P.O Box 55, \\ Rwamagana, Kayonza, Rwanda
}

(Received 30 June 2021; accepted 20 October 2021; published 21 December 2021)

\begin{abstract}
This paper describes a comprehensive review of 31 quasi or experimental research studies from the past decade on the effect of PhET simulations on students' conceptual understanding of physics. Two questions guided the review: (i) To what extent do PhET simulations enhance students' conceptual understanding of physics? (ii) What are the best ways to use PhET simulations to enhance conceptual understanding of physics? The reviewed literature provides robust evidence that PhET simulations can significantly enhance students' conceptual understanding of physics and can be integrated into many active learning instructional environments. The paper also points out gaps and directions of future research and suggests that educators integrate PhET simulations in physics to create more meaningful learning.
\end{abstract}

DOI: 10.1103/PhysRevPhysEducRes.17.023108

\section{INTRODUCTION}

McDermott (as cited by Sands [1]) defined conceptual understanding as a functional understanding or the logical ability to apply knowledge in contexts or scenarios other than the one it was generated or attained. In line with this definition, Balka et al. [2] defined conceptual understanding as a student's capability to reason in settings or environments that require careful application of concepts, descriptions, relationships, or representations. From these definitions of conceptual understanding, it can be deduced that conceptual understanding demands students' ability to synthesize information and knowledge from the known schemas and apply it in a new context. Moreover, students' conceptual understanding of physics is manifested by the ingenuity and cleverness to coordinate disparate or different bits of knowledge to solve a given problem by applying known concepts in new situations [3].

The development of conceptual understanding of physics among learners is of immense importance in the learning process for the following reasons. First, conceptual understanding should be developed among learners as it helps students connect knowledge across physics contexts so that facts and procedures should not be isolated $[4,5]$. Making

\footnotetext{
*herbertmembabanda@gmail.com

Published by the American Physical Society under the terms of the Creative Commons Attribution 4.0 International license. Further distribution of this work must maintain attribution to the author(s) and the published article's title, journal citation, and DOI.
}

connections through concept maps, mind maps, and reflections helps students integrate new concepts with ease. This promotes conceptual learning and deep learning; hence conceptual understanding is achieved. Conceptual understanding helps students make connections between what is already known to new physics phenomena. Good linkage of knowledge helps students to develop a good rapport for understanding new knowledge in physics.

Second, conceptual understanding is essential in the development of metacognition in students. Metacognition refers to higher-order thinking involving active control over the thinking process involved in learning [5,6]. It can also be defined as the study of memory monitoring and selfregulation. Metacognition involves the theoretical work where learners not only immerse themselves in content and the facts of the topic. Students are involved in processes of relating the facts to the overall explanatory frameworks, applying facts to frameworks, and testing frameworks against the facts $[4,7,8]$. Lastly, conceptual understanding is vital in helping students to transfer knowledge to new situations they encounter. Knowledge transfer is critical in empowering students to practice the theories they have acquired and accumulated from class learning. Conceptual understanding helps students in transferring conceptual physics knowledge into their daily lives [3,5,9]. Transferring the conceptual knowledge of physics to real life is a critical component of physics learning that triggers students' innovative skills.

To ensure that students develop conceptual understanding and mastery of learning in science education, teachers are encouraged to use diverse methods in their teaching [10]. That is, teachers should move for the inclusion of 
active learning methods in the classroom. Moreover, teachers should strive to create a learning environment that allows flourishing and thriving modern teaching strategies to enhance the development of conceptual understanding to meet the needs and expectations of the competitive labor market [11]. The 21st century teaching styles demand teachers to be creative and original by fully using the available resources.

One of the available resources that can and is being used in ensuring that students develop conceptual understanding in science, particularly in physics, is technology in the form of interactive simulations [11]. There are many physics simulations on the market and online free or for sale. Of particular interest in this paper are the physics education technology (PhET) simulations developed by the University of Colorado Boulder; it is a nonprofit open educational resource [12]. The PhET simulation project was initiated to improve the way science is taught and learned across the globe by using free interactive simulations. PhET simulations are renowned worldwide due to their overwhelming impact on enhancing the teaching and learning of science. PhET simulations are vital in developing a platform enriched with scientific and technological resources that enable students to engage in scientific exploration, develop conceptual understanding, make connections to everyday life, view science as accessible and enjoyable, and take ownership of the learning experience [13].

Perkins et al. [13] further emphasize that the PhET simulations are flexible and available free of charge, and address various learning goals; they are interactive, authentic, and offer meaningful learning, and are research based. This claim that PhET interactive simulations are fundamental in aiding the enhancement and development of conceptual understanding among learners in physics has sparked a bandwagon of research in this area by researchers and educators across the globe. There has been a surge in the studies concerning integrating PhET simulations on students' conceptual understanding of physics in the past decade. However, there is limited substantiated and comprehensive information obtained by analyzing the findings of these studies to establish the status quo of knowledge in this area. No literature review paper has been done to critically appraise and assess the quality of knowledge in the studies conducted and form a comprehensive and unified understanding of the stand-alone studies done in this field. In this case, it can be stated that a literature review is needed to establish, summarize, critically analyze and synthesize the relevant available research studies on the topic at hand and establish a comprehensive and holistic status quo of knowledge in this area. The data from this review will be vital in ascertaining the relevance and immense importance of $\mathrm{PhET}$ interactive simulations in enhancing conceptual understanding. Furthermore, this paper will establish the usability and feasibility of PhET simulations in various instructional designs. Lastly, this literature review will update the readers with current literature regarding this topic and point the research gaps and directions for future research in this area. Thus, this paper aims to review the available literature on this topic. In other words, this review paper investigates the effect of integrating PhET simulations on students' conceptual understanding of physics by answering the following research questions:

1. To what extent do PhET simulations enhance students' conceptual understanding of physics?

2. What are the best ways to use PhET simulations to enhance conceptual understanding of physics?

\section{METHODOLOGY}

The proposed research questions were answered by searching for relevant articles in the following databases: ERIC, Scopus, Google Scholar, and an extensive follow-up on ProQuest, Unpaywall, ResearchGate, Academia, and google search in cases they could not be downloaded from the designated databases. The search focused on journal articles that have been published between the years of 2010 to March 2021. The keywords which were used in the search of journal articles were "PhET interactive simulation OR computer simulation," "physics," and "conceptual understanding OR understanding." The term "computer simulations" was used in searching relevant studies as there are other studies that used the term computer simulation in its title or its keywords, yet in the study design and methodology, they used only PhET interactive simulations as the only computer simulation to enhance conceptual understanding in physics. The papers included in this review were analyzed by extracting their educational context, year of study, what course the study was done in, how it was measured, study design, results, statistical values, and the effect size in cases where it was calculated. In answering objective (ii), papers were grouped into four active learning designs based on the core features of each instructional design. Information on educational context, year of study, what course the study was done in, how it was measured, study design, results, statistical values, and the effect size in cases where it was calculated was extracted and analyzed.

\section{A. Inclusion and exclusion process}

Researchers' ability to demarcate the limits and boundaries and identify or create a working strategy or criteria is one of the essential skills in having a comprehensive review paper. Articles were included or excluded for analysis based on the following criteria. The studies were selected following the inclusion criteria as indicated in Table I.

The studies outside the scope of this study are those that combined $\mathrm{PhET}$ interactive simulations and other computer simulations, videos, microcontrollers, projectors, interactive whiteboards, or other ICT resources to enhance the conceptual understanding of students in physics. Again, papers that used other interactive computer simulations, not PhET interactive simulations to enhance conceptual understanding were removed. Similarly, studies that used PhET simulations to enhance conceptual understanding in 
TABLE I. Inclusion criteria that were used in selecting the articles.

\begin{tabular}{lc}
\hline \hline Criteria & Meaning \\
\hline $\begin{array}{l}\text { Time interval } \\
\text { Type of intervention simulation used to enhance } \\
\text { conceptual understanding in physics }\end{array}$ & Studies that were conducted between the years 2010 up to March 2021. \\
$\begin{array}{ll}\text { Study design } & \text { Studies that strictly used PhET interactive simulation as the only teaching } \\
& \text { resource or aid to enhance conceptual understanding in physics. } \\
\text { The outcome of the study } & \text { A study using simulation techniques by PhET simulations having an } \\
& \text { experimental or quasiexperimental design with pretest and post } \\
\text { comparison groups. } & \text { A PhET simulated study where conceptual understanding in physics is one of } \\
\text { the outcomes being measured. }\end{array}$ \\
\hline \hline
\end{tabular}

biology, mathematics, earth science, chemistry, or engineering were excluded. In cases where the article was published in several journals, one publication was used to avoid duplication.

The total number of papers that made the overall dataset was 6049 journal articles. The search that was done on the Scopus database resulted in 2856 articles. Google scholar produced 2810 articles. Again, a search in ERIC resulted in 274 articles. Articles that could not be downloaded from these databases were extensively searched on journal outlets like ProQuest and other sites like Google search, Unpaywall, academia, and ResearchGate so that relevant articles should not be missed. This extensive search yielded a total of 109 articles. The screening and eligibility assessment process reduced the number to 310 articles. At this stage, a total of 279 articles were removed as they had used PhET interactive simulations together with other interactive computer simulations or other ICT resources, they belonged to other science subjects (mathematics, chemistry, biology, earth science, or engineering), or they did not specify the type of interactive computer simulation used. A total of 31 research studies on integrating PhET simulations on conceptual understanding in physics were analyzed. Thus, a total of 31 articles were identified and included in this review. Figure 1 shows the inclusion and exclusion criteria used in this review.

\section{RESULTS AND DISCUSSION}

\section{A. To what extent do PhET simulations enhance students' conceptual understanding of physics?}

PhET simulations are increasingly becoming a powerful teaching resource for science educators across the globe. Many science educators are integrating PhET simulations into mainstream classes. Research evidence supports the notion that computer simulation-based learning

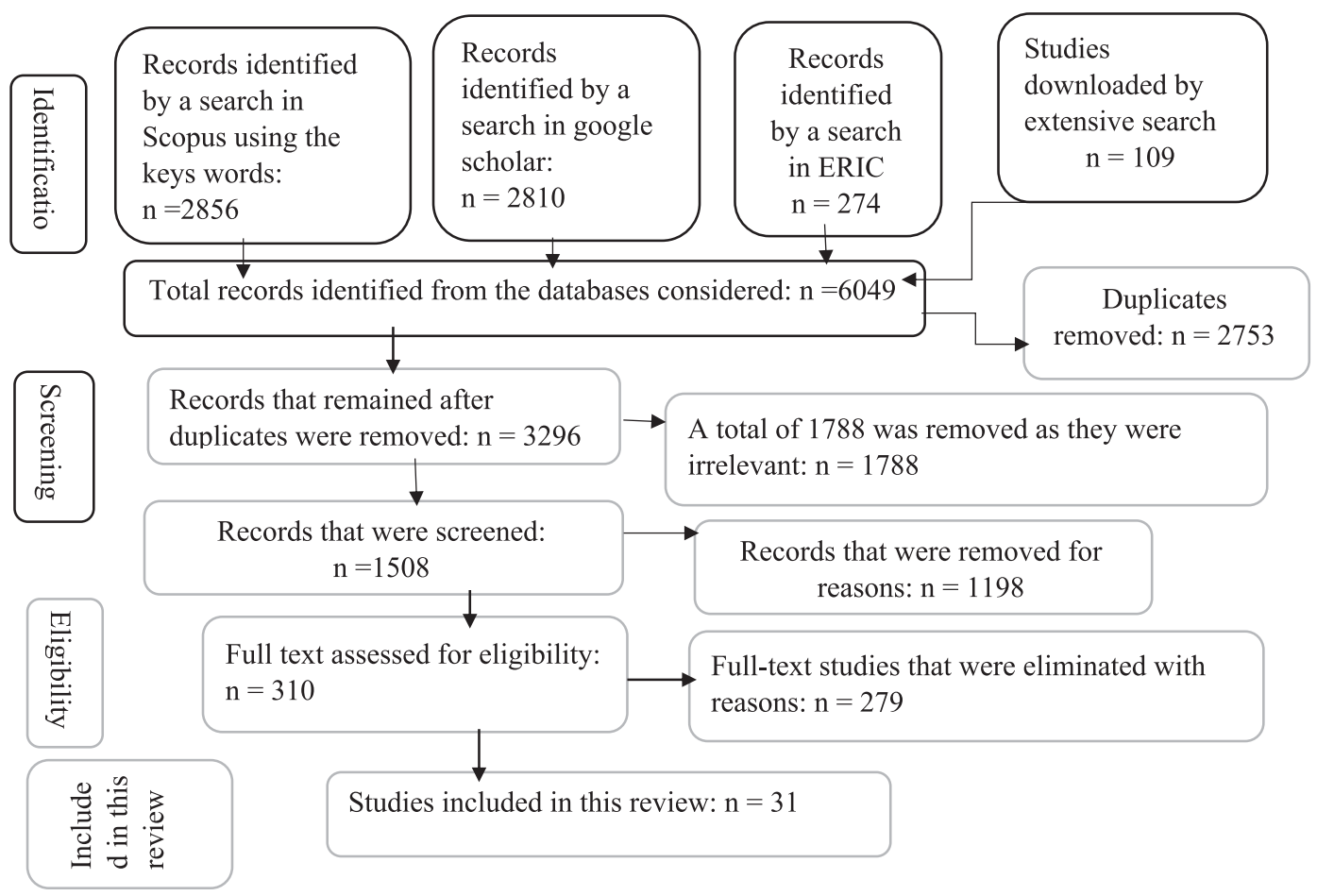

FIG. 1. Preferred reporting items for systematic reviews and meta-analysis (PRISMA; [14]) flow diagram. 
(instruction) is regarded as a cognitive visualized tool to enhance the effectiveness of learning among science students [13,15-18]. PhET simulations have been used to support activities on observation and reflection in learning abstract concepts and generate real-time data to show dynamic phenomena and information on how specific parameters are changing synchronously to spark higher orders of thinking. The following paragraphs summarize studies on what extent PhET simulations enhance students' conceptual understanding of physics.

A study by Park [19] on the effects of simulation-based formative assessment on students' conception in physics revealed that PhET simulation improved students' conception of physics. Students improved their conceptual understanding by developing skills in making scientific predictions and explaining a given phenomenon with more valid scientific ideas triggered by visuals of the PhET simulation. Park [19] and Srisawasdi and Panjaburee [20] state that PhET simulations' visual aids provide an opportunity to elicit students' pre-existing understanding and opportunities to challenge their initial understanding for conceptual change and conceptual understanding. Maulidah and Prima [21] noted that the use of PhET simulations in the teaching and learning process could enhance conceptual understanding and motivation among learners. They found that students exposed to the learning by using PhET media demonstrated a more remarkable improvement in conceptual understanding and motivation than those who had learned without PhET simulation as their teaching aid [22-25]. PhET simulation in this study improved students' cognitive skills such as factual and procedural knowledge, transfer knowledge, applying knowledge to relevant tasks, and developing inquiry and exploration skills in students [10,18,24,26].

Salameh and Aldhamit [27] conducted a study on the effect of PhET simulation learning on students' understanding of electricity and concepts and their attitudes towards physics learning. They deduced that PhET simulations improved the understanding of electricity and magnetism concepts. There was a significant difference in the post-test between the groups with a $p$ value of 0.000 . They attributed the differences in the performances between the groups due to PhET simulations that provided an opportunity for understanding concepts of electric charge and electric current by providing visualization of the phenomenon at a microscopic level. Another study by Taşlidere [28] underscored that PhET simulations are vital in improving conceptual understanding and removing students' misconceptions in the topic of direct current electric circuits (DCEC). The statistical analysis of the post-test showed that the experimental group significantly outperformed the control group in understanding the key aspects and concepts outlined in DCEC. The visualizations from PhET simulations were noted to help in outlining theoretical circuit conceptions and giving constructive feedback. This sparked students to develop the correct scientific explanations, and the immediate feedback from the PhET simulations encouraged students to think critically and scientifically.
A study by Haryadi and Pujiastuti [29] showed that the use of $\mathrm{PhET}$ simulations in learning the topic on temperature and heat produced a $37 \%$ higher normalized gain value than the control class using the conventional learning method. They emphasized the development of factual and procedural knowledge among students in the experimental group, which prodded them to analyze the concepts they had studied before [29]. Panis [30] showed a significant improvement in the conceptual understanding of physics by students in the experimental group upon being trained or taught using $\mathrm{PhET}$ interactive simulation media. Conceptual understanding was probed by asking students to demonstrate a simulation related to the learning and later explicitly explain the physics concept exhibited by the PhET simulation [24,3133]. This allowed students to build their conceptual understanding based on the given PhET simulation; hence they cemented their understanding of the physics concepts [34].

A study by Lin [35] established that PhET simulations are powerful physics learning technology in assisting students to visualize abstract concepts and connect mathematical understanding to physics concepts. PhET simulations serve the purpose of contributing to the development of conceptual understanding of physics without over-relying on the use of mathematical operators. Again, Lin [35] asserts that PhET simulations helped students develop a conceptual understanding of physics by gaining intuition on how mathematics is applied in physics. Thus, PhET simulations helped students develop the appropriate metacognitive and reflective skills needed to conduct meaningful problem solving; hence students attained the conceptual understanding of physics [22-24,35,36].

Another study by Gani et al. [37] underscored that students improved conceptual understanding by using PhET simulations on vibration and waves compared to conventional learning methods. They went on and emphasized that the scores in the post-test by the experimental group were higher than the control group. Students taught by PhET simulation were seen to have improved in thinking skills, concept analysis, creativity, and innovation skills, and ability to transfer and apply concepts and knowledge to new learning environments [2,24,37-42]. Rehman et al. [43] highlighted that students in the experimental group who were taught using PhET interactive simulation had developed a higher conceptual understanding than those taught using traditional learning methods. In line with this study, Alfajjam [44] noted that PhET simulations present the information in multiple representations that engage the students and promotes conceptual understanding instead of cramming the concepts. Lastly, Yunzal and Casinillo [45] noted a statistically significant difference $(p=0.00)$ between the experimental and control groups, with a higher improvement in the experimental group on conceptual understanding.

Table II shows studies that have been conducted to enhance conceptual understanding through the use of PhET simulations in physics. 


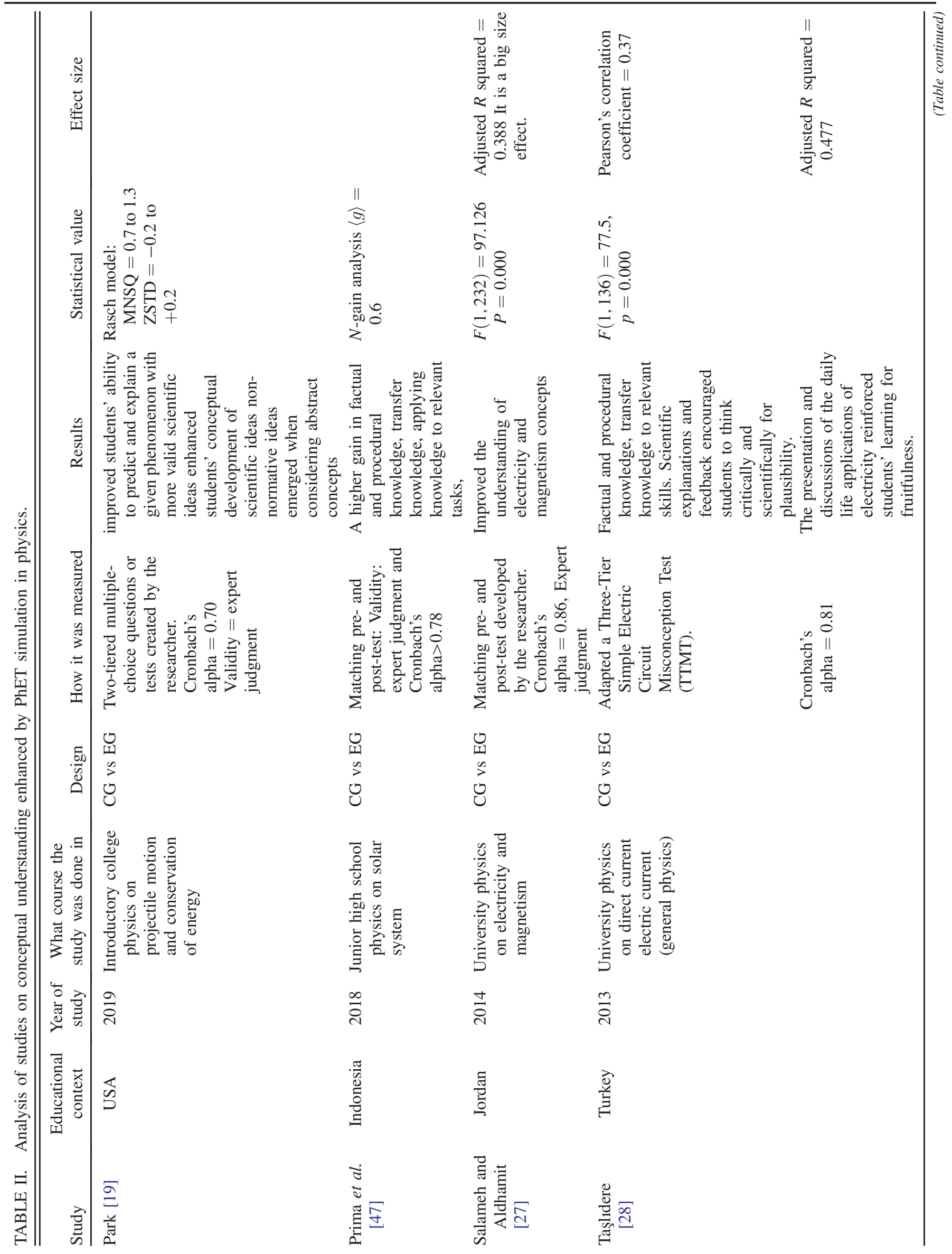




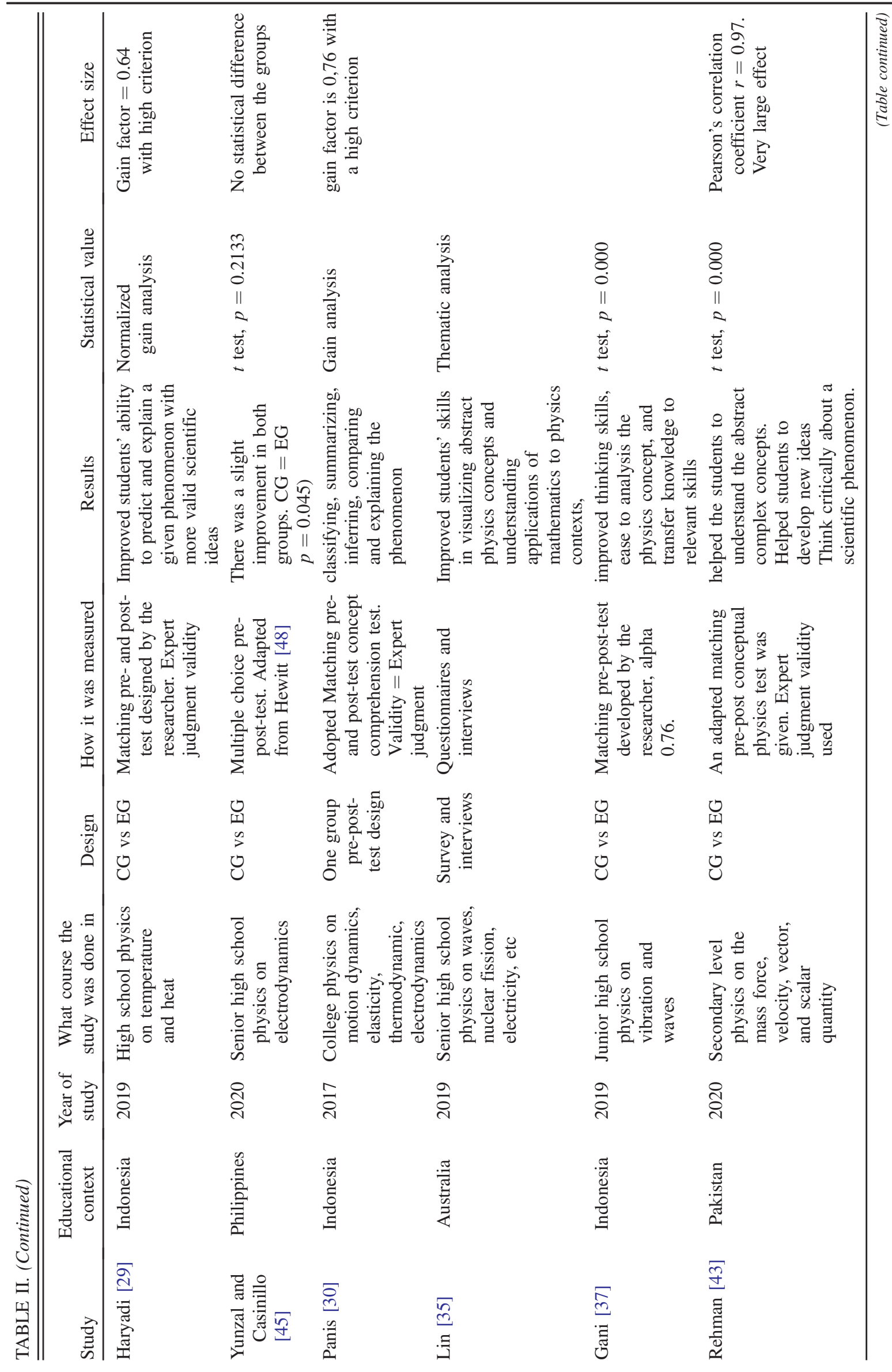




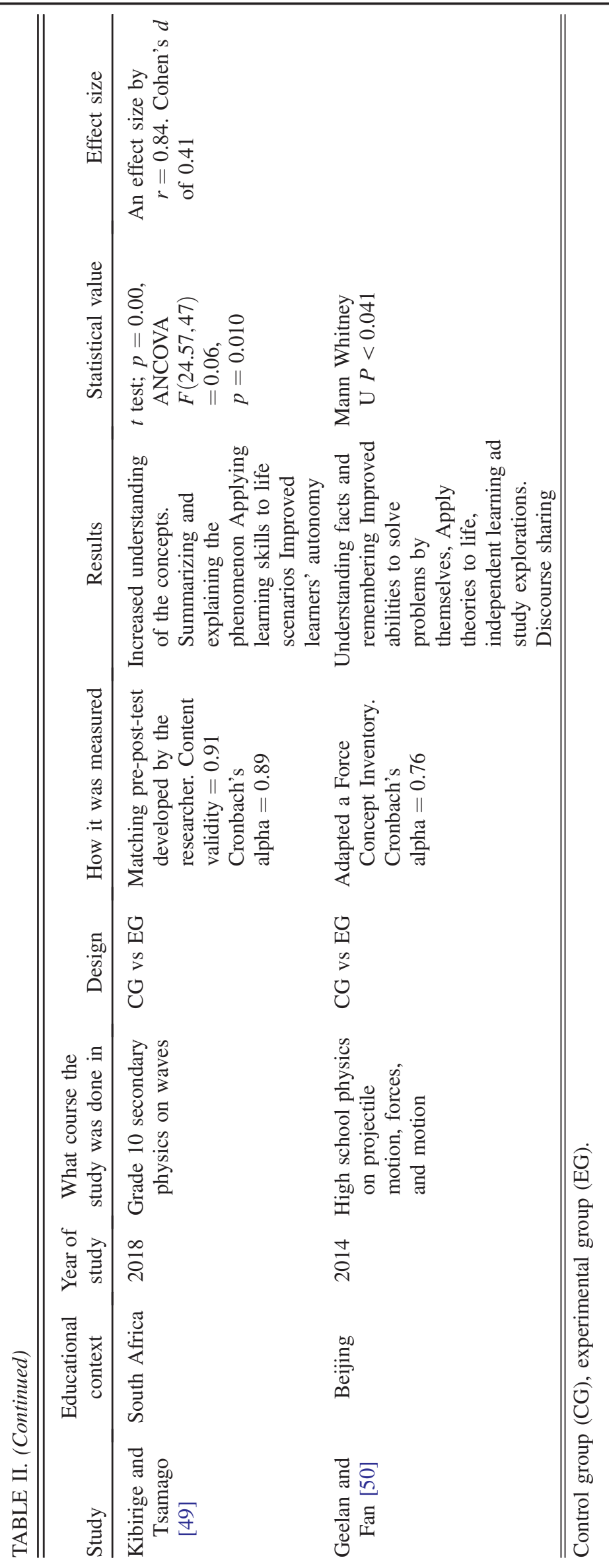


When implemented effectively, PhET simulation-based learning environments are paramount in helping students attain the appropriate conceptual understanding of physics phenomena [15]. Researchers have shown the effectiveness of PhET simulations on developing the proper conceptual understanding of physics [19,32,51-54]. Furthermore, research has established the effectiveness of PhET simulations in shaping students' conceptual understanding by studying its viability as a remedial tool to help learners correct the misconceptions they hold and provide the correct conception of the phenomena [15,19,54,55]. Again, the researchers established that PhET simulations propel learners to create and gain intuitive domain knowledge that is more of qualitative knowledge than formalized knowledge. Srisawasdi and Kroothkeaw [56] noted that PhET simulations enhance students' conceptual understanding of physics by developing metacognitive skills. Metacognitive skills helped learners obtain more theoretical backing and focus and create a more logical, comprehensive, and structured understanding of the underlying concepts.

\section{B. What are the best ways to use PhET simulations to enhance conceptual understanding of physics?}

The effectiveness of PhET simulations in the teaching and learning process is tightly connected to the pedagogy implemented in the learning situation. The effective use of multimedia teaching and learning aids in the form of dynamic simulations like PhET simulations significantly impacts the levels of knowledge in students, predominantly in performing, knowledge retrieval, conceptual understanding, knowledge transfer, and active learning $[57,58]$. Thus, this section looks into the literature on the best ways to use PhET simulations to enhance conceptual understanding of physics.

\section{Inquiry learning}

Inquiry-based learning with PhET simulations design is based on these elements: (i) Elicitation and clarification, which involves students' discussion to elicit their misconceptions. (ii) Prediction and implications to clarify students' prior conceptions on the topic. (iii) Testing the prediction of the competing conceptions through PhET simulation learning. (iv) Elucidation and linking involve clarifying the findings and linking the results to the scientific conception through students' presentations and teacher-student discussions. (v) Metacognitive evaluation and further testing. Table III shows an analysis of the studies on inquiry-based learning with PhET simulations.

A study by Fan et al. [51] acknowledged that students in the interactive simulation instruction approach (ISIA) group demonstrated more significant gains in conceptual understanding, inquiry process skills, and confidence in learning than their peers in the convention instruction group. This made Fan et al. [51] conclude that a combination of PhET simulation and inquiry-based learning is effective in enhancing student conceptual understanding, inquiry process skills, and confidence in physics learning. Husnaini and Chen [18], in their study, found that guided inquiry-based virtual laboratory by PhET simulations is effective as the physical laboratory for simple concepts. They highlighted that a guided inquiry-based virtual laboratory by $\mathrm{PhET}$ is more effective for improving the conceptual understanding of difficult concepts and scientific inquiry selfefficacy than the physical laboratory. Furthermore, Husnaini and Chen [18] acknowledge that PhET simulations provided the students with microlevel processes visuals. Students were able to see the motion of the electrons in the circuit. Thus, PhET simulations can support the understanding of physics concepts; hence, students can develop conceptual understanding and high-level cognitive thinking skills $[39,59,60]$.

Similarly, Srisawasdi and Kroothkeaw [56] found that conceptual understanding scores between pretest, post-test, and retention tests differed significantly. The test scores showed an improvement in students' conceptual understanding upon being exposed to PhET simulations. Srisawasdi and Kroothkeaw [56] asserted that conceptual change in students was attributed to the development of the cognitive structure of conceptual knowledge. This induced students to acquire scientific skills and conceptual understanding on the topic of refraction of light. Another study by Srisawasdi and Panjaburee [20] underscored that students' conceptual understanding test scores improved significantly after participating in experimental learning. It was also noted that the integration of formative assessment in simulation-based inquiry produced a better progression of scientific understanding than without formative assessment $[19,20]$. Formative assessments integrated into inquiry-based learning through simulation ensure that students' ideas and knowledge are smoothly shared, and misconceptions are corrected through recursive feedback. [61-64]. Lastly, Şenyiğit et al. [65] underscored the impact of the blended learning program of simulation-based inquiry learning on fostering more meaningful learning in physics and other science subjects through conceptual change. They noted that students in the experimental group performed better than students in the control group. There was a statistical difference between the two groups with a $p$ value of 0.006 .

There is substantial evidence from research papers that supports inquiry-based learning assisted by 


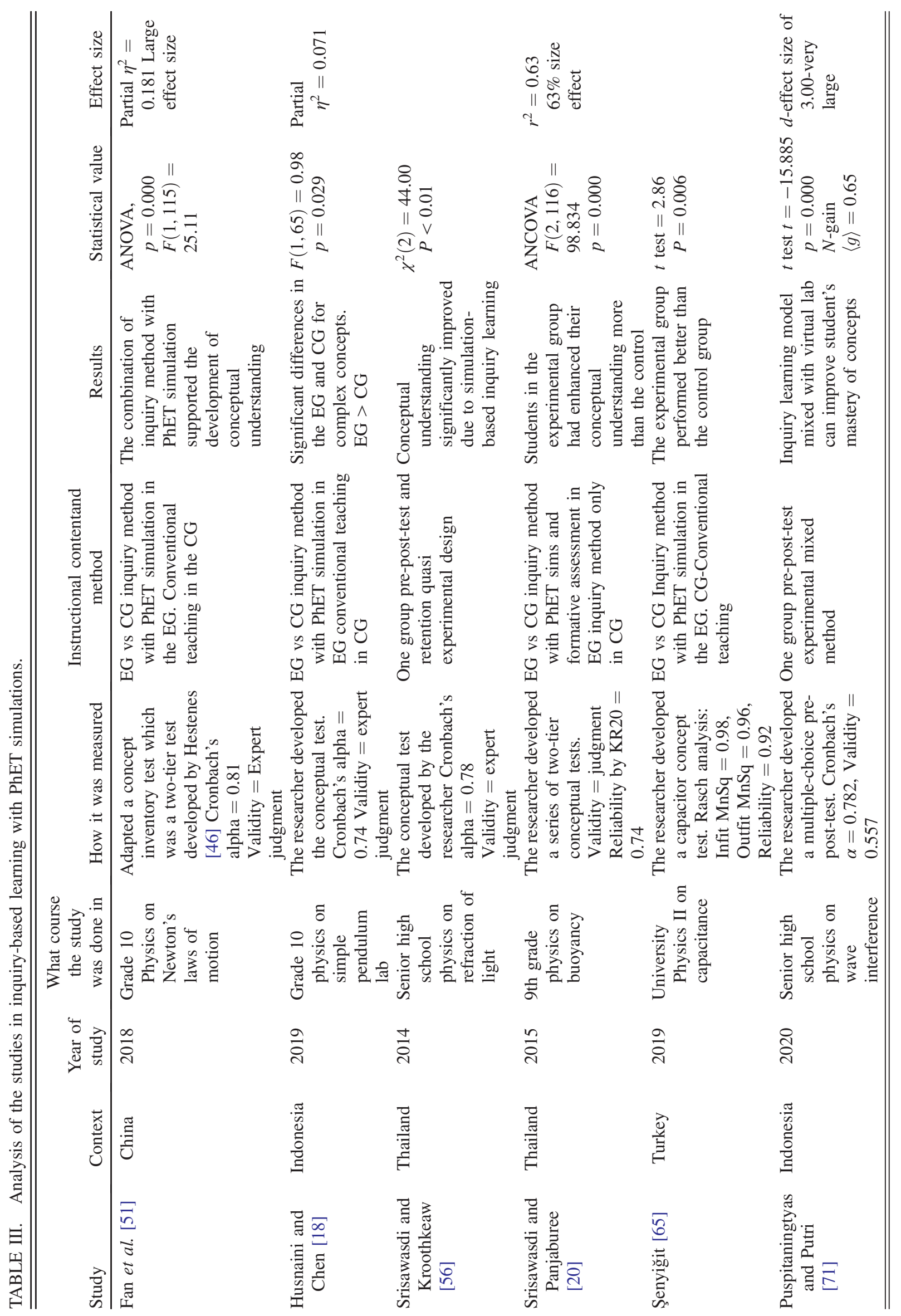


PhET simulations to enhance conceptual understanding among the learners. Inquiry-based learning aided by PhET simulations fosters the flourishment of students' conceptual understanding by deepening students' understanding of physics. It helps learners to generate their understanding about a phenomenon; hence they develop meaningful learning. The dynamic visualization of PhET simulation sparks curiosity in learners, making them engage more profoundly with the topic and content in physics; hence, they gain a deeper understanding instead of cramming, recalling the given inquiry-based facts. Inquiry-based learning assisted with $\mathrm{PhET}$ simulations also promotes students' engagement, independence, differentiated learning, and the love of physics. Lastly, inquiry-based learning assisted by PhET prompts students to ask questions, making observations, sharing ideas, and exploring more about the given phenomenon. Thus, PhET simulations in inquiry-based learning help students to create more meaningful learning.

\section{Problem-based learning}

Problem-based learning with PhET simulations is designed in a way that encompasses the following features: (i) Assigning a problem to the students at the beginning of the study, (ii) students evaluating and synthesizing knowledge they found in different sources; i.e., the internet, journals, books, etc., (iii) formulating a hypothesis and designing experiments based on the information sought, (iv) experimenting the hypothesis in PhET simulations, (v) collecting the results, interpreting, and making conclusions.

A study by Rahmawati et al. [66] on the development of e-handouts assisted by PhET simulations with problem-based learning (PBL) found that the e-handouts aided by PhET simulations are of paramount importance in improving students' conceptual understanding of physics. There were significant changes in the average scores of the students' pre-and post-test, which indicated a gain in learning outcomes after using e-handouts assisted by PhET simulations with the PBL model of learning [22,67]. Students were seen to have developed skills in conceptual understanding, critical analysis, critical thinking, self-reliance, and skills of scientific exploration, which required the students to relate, create, and donate the knowledge they acquired in their learning environment $[68,69]$. A study by Doloksaribu and Triwiyono [70] noted that students in the treatment group increased virtual experiment abilities and conceptual understanding upon being exposed to PBL with PhET simulations. There was a statistically significant difference $(p=0.001)$ in the test scores of the control and experimental group.

The studies analyzed in Table IV show that conceptual understanding can be enhanced through

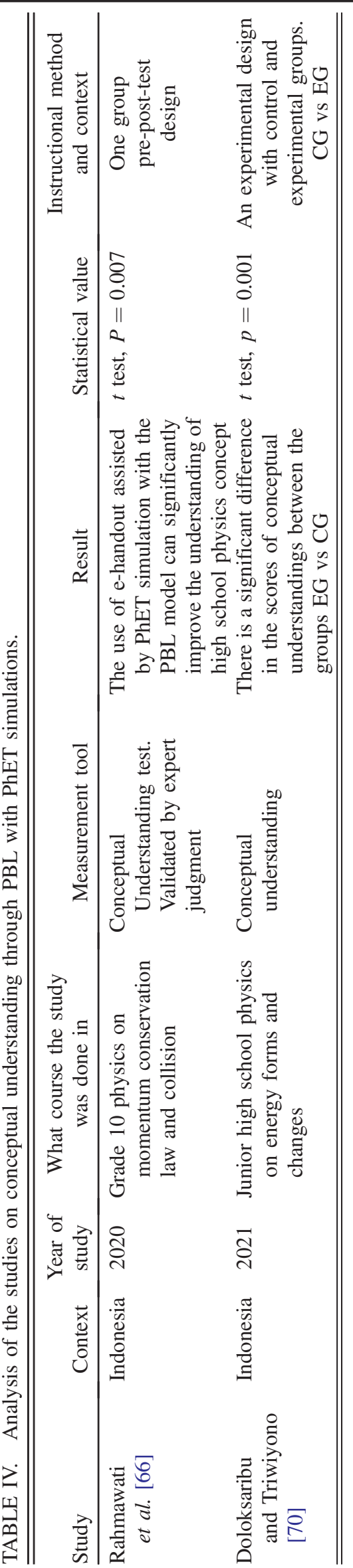


problem-based learning integrated by PhET simulations. However, further studies on this topic need to be studied in other regions across the globe to ascertain the significance of problem-based learning with PhET. More studies in this area will add valuable information to this field.

\section{Virtual laboratory experimentation}

From the studies analyzed in Table V, Faour et al. [72] noted that PhET simulations explicitly show the direct current's microscopic aspects and how it follows at the microscopic level $[27,33,55,59,73]$. The simulations on the flow of electrons helped students develop the correct conceptions on the follow of electricity; hence, the students quickly acquired the conceptual understanding of electricity concepts. Maulidah and Prima [21] focused on the use of PhET as a virtual laboratory in the teaching and learning of waves and sounds found that PhET impacted the cognitive aspects in students. These cognitive aspects are memorization, conceptual understanding, application, analysis, evaluation, creation, and scientific experimentation skills. PhET simulations were noted to impact students' understanding by combining theory and a virtual laboratory for experimenting [21].

Farrokhnia and Esmailpour [73] studied the impact of real, virtual, and comprehensive experimenting on students' conceptual understanding of dc electric circuits and their skills in undergraduate electricity experiments. They found that PhET simulations significantly impact students' conceptual learning, which invokes deeper learning and conceptual understanding, just as in the physical laboratory. However, Farrokhnia and Esmailpour [73] noted that PhET simulations combined with physical laboratory activities significantly impact students' conceptual understanding with a value of $p=0.021$. Ajredini et al. [75] indicated that experimentation with PhET simulations has the same level of impact on conceptual understanding as physical laboratory experimentation. The physical experimentation group and PhET simulations group showed similar traits in conceptual understanding on post-test. Ajredini et al. [75] concluded that PhET simulations could substitute for physical laboratories when the physical laboratory is inaccessible.

Supurwoko et al. [74] demonstrated that PhET simulations, when used as a virtual laboratory, are very productive in developing students' conceptual understanding of the photoelectric effect compared to the traditional learning style. It was noted in this study that students were able to construct their understanding of the photoelectric effect within the designated frameworks. Research by other scholars on computer

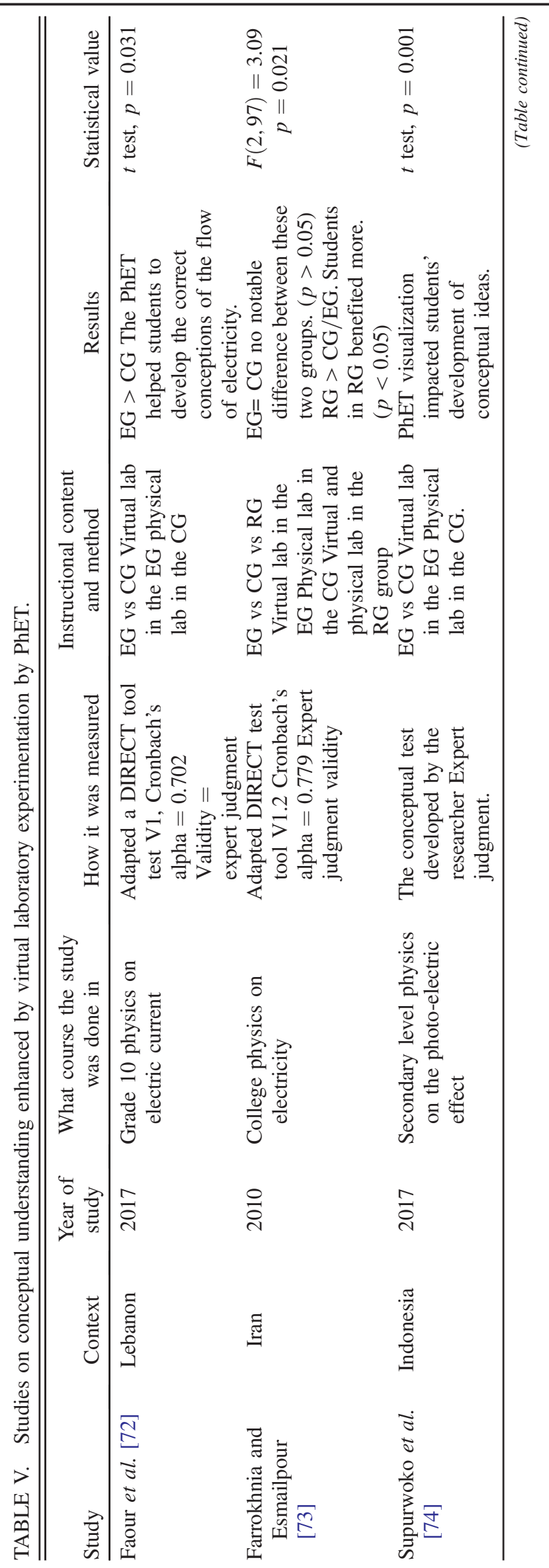




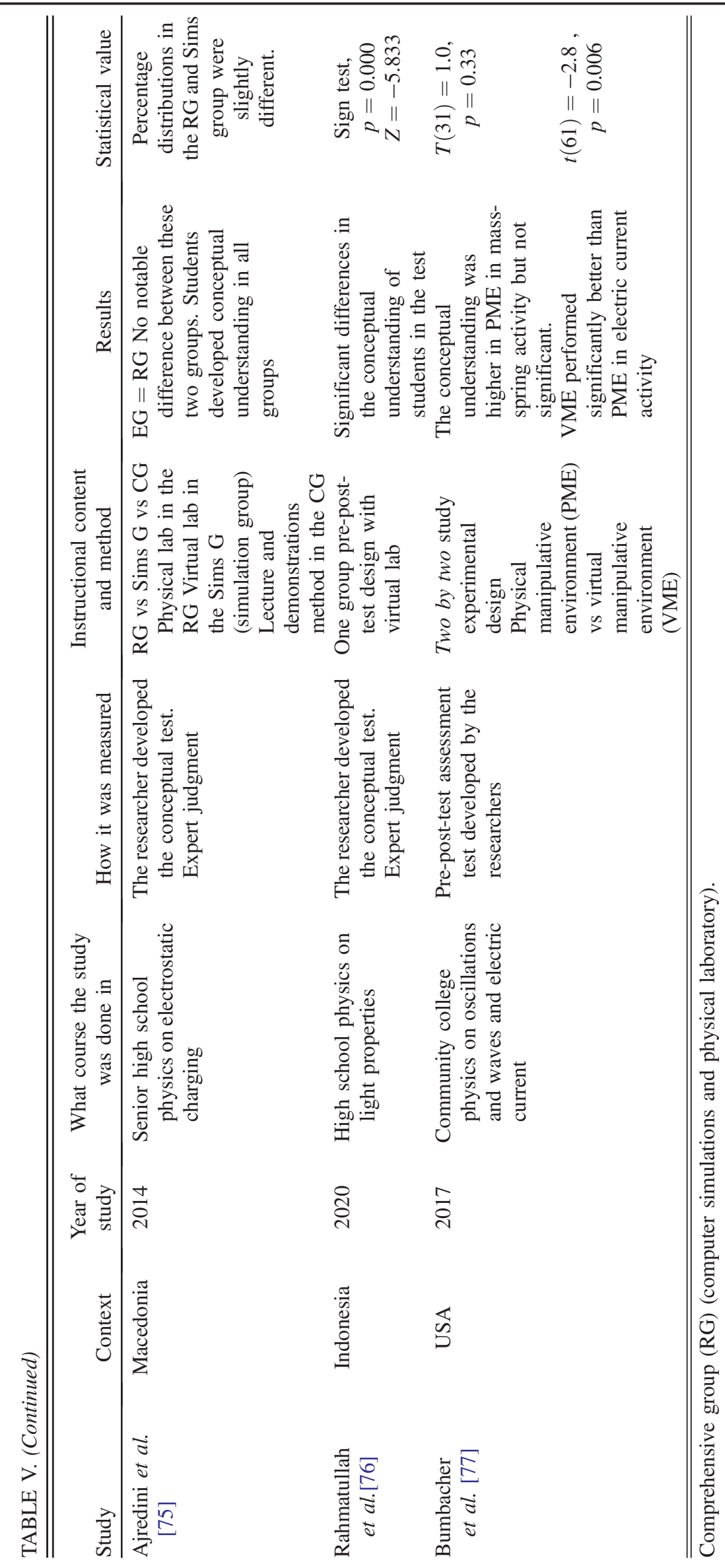


simulations agrees with Supurwoko et al. [74] by noting that simulations helped clarify abstract concepts showing how electrons were jumping from the metal in the photoelectric effect $[24,42,52,69]$. This helped students to develop the correct conceptualization of the photoelectric effect phenomena.

Rahmatullah et al. [76] acknowledged that using contextual physics teaching materials with the help of an android-based virtual lab by PhET simulations improved students' conceptual understanding of physics. The findings in this study are vital in showing that physics teaching material assisted by PhET simulations android-based virtual laboratories are of paramount importance in improving students' conceptual understanding [24,76,78]. The android-based PhET simulations are significant in enhancing laboratory activities by making the virtual laboratory aspect ubiquitous. Students can do experiments right in the comfort of their homes without going to school in the COVID-19 pandemic period [76]. Bumbacher et al. [77] noted that manipulative environments (PME/VME) affect conceptual understanding development differently depending on the topic at hand. Some topics in physics will favor the use of physical manipulative environments for students to develop the correct conceptions of the phenomenon better than virtual manipulation environments and vice versa.

The reviewed studies on PhET simulations being used in virtual laboratory experimentation to enhance conceptual understanding in physics underscored the significance of PhET simulation in virtual experiments to improve conceptual understanding. Virtual laboratories by $\mathrm{PhET}$ simulations enhance conceptual understanding by helping facilitators explicitly explain the microscopic aspect of the phenomena to the students. Learners are given a platform where they can indulge and conduct all kinds of experiments without the fear of damaging the apparatus or injuring themselves. Furthermore, learners can try the experiments virtually and know the working procedure before conducting it in the laboratory, and through several trys, they can deduce the best laboratory protocol. That is, PhET simulations can be used in pre-laboratory exercises. This can help learners predict, explain, and test the hypothesis; hence learners can develop a correct conceptual understanding of physics concepts. Thus, a PhET virtual laboratory can make up for a physical laboratory when schools do not have well-furnished laboratories.

\section{Scaffolding learning}

Scaffolding learning looks at helping learners to fill in crucial gaps in abilities and knowledge such that they should work at completing the given task with maximum goal attainment. Scaffolding learning calls on facilitators to adjust the amount of guidance given to learners to meet the potential level of performance of the students. The scaffolding function which this paper digs deeper into is conceptual scaffolding. Conceptual scaffolding with PhET simulations takes the form of expert modeling in which an expert discusses what aspects of the problem they would consider in solving the problem. Planning animations and virtual experiments with guidance from the teacher highlighting areas of significant importance to the learning goals. Lastly, scaffolding learning with PhET simulations engages students to develop concept maps that outline the crucial material learned. Scaffolding learning with PhET simulations in physics has been used, and it is a developing field. Table VI shows studies on scaffolding with PhET in physics.

Studies by Eveline et al. [79], Ardiyati et al. [78], and Utami et al. [80] noted that scaffolding learning with the integration of PhET simulations enhanced conceptual understanding from the descriptive analysis. Test scores from these studies highlighted that the scaffolding approach with PhET allowed students to develop the correct conceptual understanding of physics. They could not ascertain the significance of the changes in the post-test score by using inferential statistics. Eveline et al. [79], Ardiyati et al. [78] and Utami et al. [80] acknowledge the need for more studies with large participants to compare results in this area. Mahtari et al. [81] noted that students' conceptual understanding of physics improved through scaffolding learning with PhET simulations by recording a medium category of a gain analysis (0.48). Lastly, Moser et al. [82] noted that scaffolding learning with PhET simulations increased students' performance and conceptual understanding on the post-test by using descriptive statistics. However, inferential statistics show no significant differences in the control and experimental groups $(p=0.68)$ with an effect size of 0.00 .

Studies on scaffolding learning assisted by PhET simulations in physics have shown that students improve their conceptual understanding and attain meaningful learning substantiated by the visualization which PhET simulations provide descriptively. However, research on scaffolding learning with PhET simulations in physics is inconclusive as there are many gaps and discrepancies in results due to the small sample size used in the previous studies. Thus, more studies with a large sample size are needed to establish coherent knowledge in this field and make generalizations. 


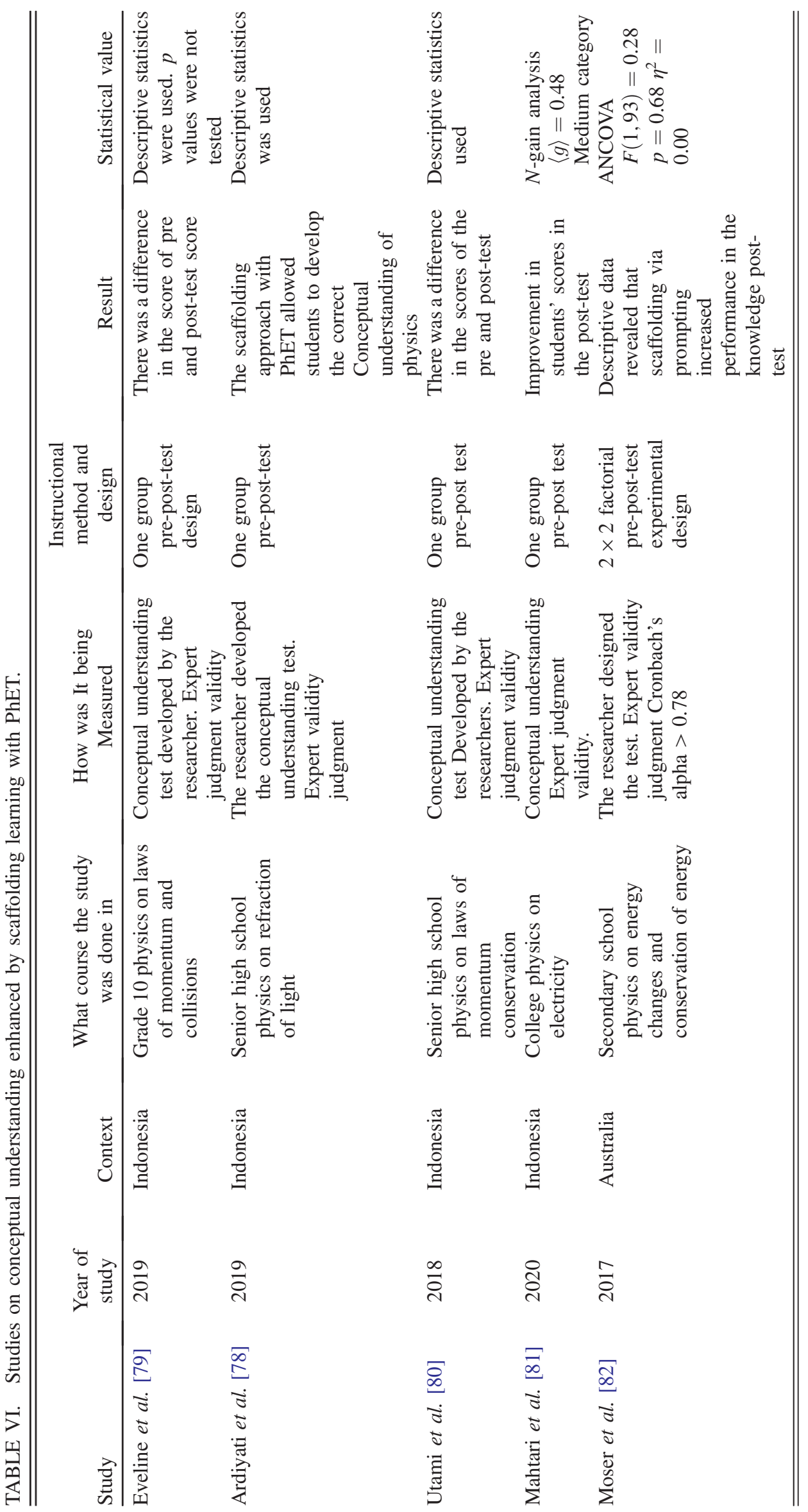




\section{CONCLUSION}

This paper presents a systematic review of the research studies investigating the effects of PhET simulations on students' physics conceptual understanding in the past decade. The paper addressed the following research questions regarding the efficacy of using simulations in physics education. (1) To what extent do PhET simulations enhance students' conceptual understanding of physics? (2) What are the best ways to use PhET simulations to enhance conceptual understanding of physics? The key findings are that (i) there is a large number of research papers showing that PhET simulations are effective at developing students' conceptual understanding in various physics topics; (ii) instructional strategies for using PhET simulations to improve conceptual understanding include inquiry-based activities, virtual lab experimentation, problem-based learning activities, and scaffolded learning activities. These studies and results span from many different countries and education systems.

This paper recommends integrating PhET simulations in the teaching and learning of physics. They offer a teaching aid with powerful interactive visualizations and animations to enhance students' conceptual understanding of physics.
These visualizations can meet the learning needs of $21 \mathrm{st}$ century digital learners in any learning design to enhance conceptual understanding in physics. Teachers should embrace and spearhead the integration of PhET simulations in the teaching and learning of physics.

However, there is an urgent need for further studies to ascertain the impact of collaborative and group learning methods assisted by $\mathrm{PhET}$ simulations to enhance conceptual understanding in physics as it is an active area of study with little or no research done currently. Also, this study noted the need for the study on the effect of PhET simulation-based learning on students' cognitive engagement and conceptual understanding as it is currently an untapped field of study in education.

\section{ACKNOWLEDGMENTS}

The authors wish to acknowledge colleagues for the insightful comments and corrections rendered in this work. Financial support provided by the African Centre of Excellence for Innovative Teaching and Learning Mathematics and Science (ACEITLMS) is thankfully acknowledged.
[1] D. Sands, Concepts and conceptual understanding: What are we talking about?, High. Educ. Acad. 10, 7 (2014).

[2] T. Hull, M. Harbin, and D. Balka, What is conceptual understanding?, https://nild.org/wp-content/uploads/2015/ 02/What-is-Conceptual-Understanding.pdf, accessed 4 April 2021.

[3] S. Mills, A grounded theory of the process of conceptual understanding in baccalaureate nursing students learning medication calculations, Ph.D. thesis, ProQuest Diss. Theses, Widener University School of Nursing, 2012.

[4] S. Harrison and C. Gibbons, Nursing student perceptions of concept maps: From theory to practice, Nurs. Educ. Perspect. 34, 395 (2013).

[5] S. Mills, Conceptual understanding: A concept analysis, Quality Control Reports 21, 546 (2016).

[6] B. Cope and M. Kalantzis, Conceptualizing e-Learning (Routledge, New York, 2016).

[7] A. Milligan and B. Wood, Conceptual understandings as transition points: Making sense of a complex social world, J. Curric. Stud. 42, 487 (2010).

[8] P. K. Hardin and S. J. Richardson, Teaching the concept curricula: Theory and method, J. Nurs. Educ. 51, 155 (2012).

[9] A. Jansen, Developing productive dispositions during small-group work in two sixth grade mathematics classrooms: Teachers' facilitation efforts and students' selfreported benefits, Middle Grades Res. J. 7, 37 (2012), http://udel.edu/ jansen/Jansen_MGRJ_2012.pdf.
[10] A. Mbonyiryivuze, L. L. Yadav, and M. M. Amadalo, Students' conceptual understanding of electricity and magnetism and its implications: A review, African J. Educ. Stud. Math. Sci. 15, 55 (2019).

[11] J. Osborne and S. Hennessy, Literature review in science education and the role of ICT: Promise, problems and future directions, Futur. Ser. 1 (2003), https://www.nfer.ac .uk/publications/FUTL74/FUTL74.pdf.

[12] See https://phet.colorado.edu/.

[13] K. K. Perkins, E. B. Moore, and S. V Chasteen, Examining the use of PhET interactive simulations in US college and high school classrooms, in Proceedings of the 2014 Physics Education Research Conference, Minneapolis, MN (AIP, New York, 2014), pp. 207-210.

[14] A. Liberati, D. G. Altman, J. Tetzlaff, C. Mulrow, P. C. Gøtzsche, J. P. A. Ioannidis, M. Clarke, P. J. Devereaux, J. Kleijnen, and D. Moher, The PRISMA statement for reporting systematic reviews and meta-analyses of studies that evaluate healthcare interventions: Explanation and elaboration, PLoS Med. 6, 1 (2009).

[15] Y.-L. Chen, P.-R. Pan, Y.-T. Sung, and K.-E. Chang, Correcting misconceptions on electronics: Effects of a simulation-based learning environment backed by a conceptual change model, J. Educ. Technol. Soc. 16, 212 (2013), http://www.jstor.org/stable/jeductechsoci.16.2.212.

[16] N. Govender, Effects of ICT simulation and traditional experiments on preservice students' experiences in the concept of photo electric effects, in Proceedings: Towards 
Effective Teaching and Meaningful Learning in Mathematics, Science and Technology. ISTE International Conference on Mathematics, Science and Technology Education (2011), pp. 461-472, http://hdl.handle.net/10500/22345.

[17] C. Wieman, W. Adams, P. Loeblein, and K. Perkins, Teaching physics using PhET simulations, Phys. Teach. 48, 225 (2010).

[18] S. J. Husnaini and S. Chen, Effects of guided inquiry virtual and physical laboratories on conceptual understanding, inquiry performance, scientific inquiry, selfefficacy, and enjoyment, Phys. Rev. Phys. Educ. Res. 15, 010119 (2019).

[19] M. Park, Effects of simulation-based formative assessments on students' conceptions in physics, Eurasia J. Math. Sci. Technol. Educ. 15, 1 (2019).

[20] N. Srisawasdi and P. Panjaburee, Exploring the effectiveness of simulation-based inquiry learning in science with the integration of formative assessment, J. Comput. Educ. 2, 323 (2015).

[21] S. S. Maulidah and E. C. Prima, Using physics education technology as virtual laboratory in learning waves and sounds, J. Educ. Sci. Learn. 1, 116 (2018).

[22] J. L. Anderson and S. D. Wall, Kinetic physics: Conceptualization of motion through visualization and embodiment, J. Sci. Educ. Technol. 25, 161 (2016).

[23] Y. L. Chen, Y. R. Hong, Y. T. Sung, and K. E. Chang, Efficacy of simulation-based learning of electronics using visualization and manipulation, Educ. Technol. Soc. 14, 269 (2011), https://www.researchgate.net/publication/ 220374479_Efficacy_of_Simulation-Based_Learning of_Electronics_Using_Visualization_and_Manipulation.

[24] A. Kohnle, C. Baily, and S. Ruby, Investigating the influence of visualization on student understanding of quantum superposition, in Proceedings of the 2014 Physics Education Research Conference, Minneapolis, MN (AIP, New York, 2014), pp. 139-142.

[25] K. Scalise, M. Timms, A. Moorjani, L. Clark, K. Holtermann, and P. S. Irvin, Student learning in science simulations: Design features that promote learning gains, J. Res. Sci. Teach. 48, 1050 (2011).

[26] A. Widiyatmoko, The effectiveness of simulation in science learning on conceptual understanding: A literature review, J. Res. Sci. Teach. 24, 35 (2018).

[27] M. Salameh and Y. Aldhamit, The effect of computer simulation on Al-Hussein Bin Talal University student's understanding of electricity and magnetism concepts and their attitudes towards physics learning, Int. J. Educ. Res. Technol. 5, 54 (2014), http://soeagra.com/ijert/ ijertmarch2014/12.pdf.

[28] E. Taşlıdere, Effect of conceptual change oriented instruction on students' conceptual understanding, and decreasing their misconceptions in dc electric circuits, Creat. Educ. 04, 273 (2013).

[29] R. Haryadi and H. Pujiastuti, PhET simulation softwarebased learning to improve science process skills, J. Phys. Conf. Ser. 1521, 022017 (2020).

[30] I. C. Panis, The utilizing of PhET simulation as a computer-based learning media to improve the understanding of college student's physics concepts, Adv. Soc. Sci. Educ. Humanit. Res. 66, 55 (2017).
[31] A. Samsudin, G. D. Putra, D. Saepuzaman, and A. H. Aminudin, A development of PhET based mechanical fluid worksheet to identify changes in student conceptions, Test Eng. Manag. 83, 15441 (2020), https://www.researchgate .net/publication/341882203_A_Development_of_PhET_ based_Mechanical_Fluid_Worksheet_to_identify_changes_ in_student_conceptions.

[32] R. Haryadi and H. Pujiastuti, Phet simulation softwarebased learning to improve understanding ability in light concept, in Proceedings of the First International Conference on Technology and Educational Science (EAI, 2019), pp. 1-5, 10.4108/eai.21-11-2018.2282121.

[33] T. Jaakkola, S. Nurmi, and K. Veermans, A comparison of students' conceptual understanding of electric circuits in simulation only and simulation-laboratory contexts, J. Res. Sci. Teach. 48, 71 (2011).

[34] A. Gunhaart and N. Srisawasdi, Effect of integrated computer-based laboratory environment on students' physics conceptual learning of sound wave properties, Procedia Soc. Behav. Sci. 46, 5750 (2012).

[35] E. C. Lin, High School Students' Perceptions about the Helpfulness of PhET Simulations for Learning Physics (Queensland University of Technology, Queensland, Australia, 2020), 10.5204/thesis.eprints.201913.

[36] L. S. M. Piyatissa, M. G. Md Johar, and A. K. Tarofder, Evaluating the effectiveness of a phet simulation for teaching and learning of "turning effect of force" in physics at secondary school level, Int. J. Adv. Res. Publ. 2, 32 (2018), http://paper.researchbib.com/view/paper/213380.

[37] A. Gani et al., Improving concept understanding and motivation of learners through PhET simulation word, J. Phys. Conf. Ser. 1567, 042013 (2020).

[38] Z. C. Zacharia and G. Olympiou, Physical versus virtual manipulative experimentation in physics learning, Learn. Instr. 21, 317 (2011).

[39] G. Olympiou, Z. C. Zacharia, and T. de Jong, Making the invisible visible: Enhancing students' conceptual understanding by introducing representations of abstract objects in a simulation, Instr. Sci. 41, 575 (2013).

[40] Y.S. Kusumah, S. Darwis, and J. D. Afgani, Developing conceptual understanding and procedural fluency for junior high school students through model-facilitated learning (MFL), Eur. J. Sci. Math. Educ. 4, 67 (2016), https://eric.ed .gov/?id=EJ1107766.

[41] P. Phanphech, T. Tanitteerapan, and E. Murphy, Explaining and enacting for conceptual understanding in secondary school physics, Issues Educ. Res. 29, 180 (2019), https:// eric.ed.gov/?id=EJ1203436.

[42] B. J. Kunnath, The Effect of Computer Simulations on Grade 12 Learners' Understanding of Concepts in the Photoelectric Effect (University of South Africa, Pretoria, 2017).

[43] N. Rehman, A. Mahmood, W. Zhang, and F. Alam, Teaching physics with interactive computer simulation at secondary level, Brazilian J. Educ. Technol. Soc. 14, 127 (2021).

[44] H. Alfajjam, Teaching Primary Science with Computer Simulation-An Intervention Study in the State of Kuwait (Durham University, Durham, England, 2013), http:// 
etheses.dur.ac.uk/8493/1/Hasan_alfajjam_Thesis_25-102013.pdf?DDD29+=.

[45] A. N. Yunzaland L. F. Casinillo, Effect of physics education technology (PhET) simulations: Evidence from STEM students' performance, J. Educ. Res. Eval. 4, 221 (2020).

[46] D. Hestenes, M. Wells, and G. Swackhamer, Force Concept Inventory, Phys. Teach. 30, 141 (1992).

[47] E. C. Prima, A. R. Putri, and N. Rustaman, Learning Solar System using PhET simulation to improve students' understanding and motivation, J. Sci. Learn. 1, 60 (2018).

[48] P. G. Hewitt, Practicing Physics Conceptual Physics, 10 th ed. (Pearson Education Inc, New York, 2006).

[49] I. Kibirige and H. E. Tsamago, Grade 10 learners' science conceptual development using computer simulations, Eurasia J. Math. Sci. Technol. Educ. 15, 1 (2019).

[50] D. Geelan and X. Fan, A Novel Instructional Sequence for Interactive Simulations (ISIS): Developing Conceptual Understanding in Physics Education in China within a Context of Curricular Reform Author Downloaded from Griffith Research Online A Novel Instructional Sequence for, in Proceedings of the 2014 International Conference of Educational Innovation Through Technology, EITT 201 (IEEE, Brisbane, Australia, 2014), pp. 1-9, 10.1109/ EITT.2014.41.

[51] X. Fan, D. Geelan, and R. Gillies, Evaluating a novel instructional sequence for conceptual change in physics using interactive simulations, Educ. Sci. 8, 1 (2018).

[52] I. M. Greca and O. J. Freira, Teaching introductory quantum physics and chemistry: caveats from the history of science and science teaching to the training of modern chemists, Chem. Educ. Res. Pract. 15, 286 (2014).

[53] E. Bozkurt, A. Ilik, E. Bozkurta, and A. Ilik, The effect of computer simulations over students' beliefs on physics and physics success, Procedia Soc. Behav. Sci. 2, 4587 (2010).

[54] D. Kaltakci-Gurel, A. Eryilmaz, and L. C. McDermott, Identifying pre-service physics teachers' misconceptions and conceptual difficulties about geometrical optics, Eur. J. Phys. 37, 045705 (2016).

[55] U. Ramnarain and S. Moosa, The use of simulations in correcting electricity misconceptions of grade 10 South African physical sciences learners, Int. J. Innov. Sci. Math. Educ. 25, 1 (2017), https://openjournals.library.sydney.edu .au/index.php/CAL/article/download/11580/11436.

[56] N. Srisawasdi and S. Kroothkeaw, Supporting students' conceptual development of light refraction by simulationbased open inquiry with a dual-situated learning model, J. Comput. Educ. 1, 49 (2014).

[57] J. Stebila, Research and prediction of the application of multimedia teaching aid in teaching technical education on the 2nd level of primary schools, Informatics Educ. 10, 105 (2011).

[58] F. Landriscina, Simulation and Learning: A ModelCentered Approach (Springer, New York, 2013).

[59] Z. Zacharia and T. de Jong, The effects on students' conceptual understanding of electric circuits of introducing virtual manipulatives within a physical manipulativeoriented curriculum, Cognit. Instr. 32, 101 (2014).

[60] K. Chien, C. Tsai, H. Chen, W. Chang, and S. Chen, Learning differences and eye fixation patterns in virtual and physical science laboratories, Comput. Educ. 82, 191 (2015).

[61] M. Peffer, L. Matthew, M. Beckler, C. Schunn, R. Maggie, and A. Revak, Science classroom inquiry (SCI) simulations: A novel method to scaffold science learning, PLoS One 10, 1 (2016).

[62] L. Lin, Y. Hsu, and Y. Yeh, The role of computer simulation in an inquiry-based learning environment: Reconstructing geological events as geologists, J. Sci. Educ. Technol. 21, 370 (2012).

[63] X. Fan, Effectiveness of an Inquiry-based Learning using Interactive Simulations for Enhancing Students' Conceptual Understanding in Physics (The University of Queensland, Queensland, Australia, 2015), 10.14264/uql.2015 .1005 .

[64] J. S. Nurreda, The development of student worksheet based guided inquiry with PhET simulation on work and energy topic, J. Penelit. Bid. Pendidik. 25, 16 (2019), https://jurnal .unimed.ac.id/2012/index.php/penelitian/article/view/ 15523.

[65] Ç. Şenyiğit, F. Önder, and İ. Sılay, An inquiry-based learning approach for effective concept teaching, Inq. Educ. 13, 10 (2021), https://files.eric.ed.gov/fulltext/ EJ1308214.pdf.

[66] E. Rahmawati, D. Jumadi, and D. Astuti, Development of e-handout assisted by PhET simulation with problembased learning (PBL) model about momentum conservation law, and collision to train students' conceptual understanding, J. Phys. Conf. Ser. 1440, 012048 (2020).

[67] E. S. Quellmalz, M. J. Timms, M. D. Silberglitt, and B. C. Buckley, Science assessments for all: Integrating science simulations into balanced state science assessment systems, J. Res. Sci. Teach. 49, 363 (2012).

[68] L. K. Smetana and R. L. Bell, Computer simulations to support science instruction and learning: A critical review of the literature, Int. J. Sci. Educ. 34, 1337 (2012).

[69] N. Simon, Simulated, and virtual science laboratory experiments: improving critical thinking, and higher-order learning skills, in Proceedings of the Society for Information Technology, and Teacher Education International Conference (AACE, Waynesville, NC, USA, 2014), pp. 453-459, https://www.learntechlib.org/primary/p/ 130788/.

[70] F. E. Doloksaribu and T. Triwiyono, The reconstruction model of science learning based PhET-problem solving, Int. J. Stud. Educ. 3, 37 (2021).

[71] E. Puspitaningtyas and E. F. N. Putri, Analysis of high school students' mastery in lightwave theory using structured inquiry learning assisted by a virtual laboratory, Rev. Mex. Física 18, 10 (2021).

[72] M. A. Faour, Z. Ayoubi, and Z. The, The effect of using virtual laboratory on grade 10 students' conceptual understanding and their attitudes towards physics, J. Educ. Sci. Environ. Heal. 4, 54 (2018).

[73] M. R. Farrokhnia and A. Esmailpour, A study on the impact of real, virtual and comprehensive experimenting on students' conceptual understanding of dc electric circuits and their skills in undergraduate electricity, Procedia Soc. Behav. Sci. 2, 5474 (2010). 
[74] S. Supurwoko, C. Cari, S. Sarwanto, S. Sukarmin, R. Budiharti, and T. S. Dewi, Virtual lab experiment: Physics educational technology (PhET) photo-electric effect for senior high school, Int. J. Sci. Appl. Sci. Conf. Ser. 2, 381 (2017).

[75] F. Ajredini, N. Izairi, and O. Zajkov, Real experiments versus PhET simulations for better high-school students' understanding of electrostatic charging, Eur. J. Phys. Educ. 5, 59 (2014), https://files.eric.ed.gov/fulltext/EJ1051517 .pdf.

[76] Rahmatullah, W. S. B. Dwandaru, H. Kuswanto, and A. Karanggulimu, The effect of contextual physics teaching materials assisted by an android-based virtual lab to improve students' conceptual understanding during the COVID-19 pandemic, in Proceedings of the 6th International Seminar on Science Education (ISSE 2020) (2021), pp. 502-508, 10.2991/assehr.k.210326.072.

[77] E. Bumbacher, S. Salehi, C. Wieman, and P. Blikstein, Tools for science inquiry learning: tool affordances, experimentation strategies, and conceptual understanding, J. Sci. Educ. Technol. 27, 215 (2018).
[78] T. K. Ardiyati, I. Wilujeng, H. Kuswanto, and Jumadi, The effect of scaffolding approach assisted by PhET simulation on the achievement of science process skills in physics, J. Phys. Conf. Ser. 1233, 012035 (2019).

[79] E. Eveline, I. Wilujeng, and H. Kuswanto, The effect of scaffolding approach assisted by PhET simulation on students' conceptual understanding and students' learning independence in physics, J. Phys. Conf. Ser. 1233, 012036 (2019).

[80] T. Utami, I. Wilujeng, and H. Kuswanto, Subject specific pedagogy development with scaffolding approach assisted by PhET simulation on momentum conservation law to improve students ' conceptual understanding and learning independence, J. Phys. Conf. Ser. 1233, 012066 (2019).

[81] S. Mahtari, M. Wati, S. Hartini, M. Misbah, and D. Dewantara, The effectiveness of the student worksheet with PhET simulation used scaffolding question prompt, J. Phys. Conf. Ser. 1422, 012010 (2020).

[82] S. Moser, I. Deibl, and J. Zumbach, The effect of metacognitive training and prompting on learning success in simulation-based physics learning, Sci. Educ. 101, 944 (2017). 